\title{
Management of a patient undergoing sitting position craniotomy for acoustic neuroma with co-existing interstitial lung disease
}

\author{
Deepa Suvarna, Lipika Baliarsing, Pinakin Gujjar, Rashmi Agarwal
}

\begin{abstract}
A 38-year-old woman with acoustic neuroma associated with occupational interstitial lung disease (ILD) was successfully managed for sitting position craniotomy using carefully titrated desflurane-based anaesthesia. The anaesthetic challenges included maintenance an adequate depth of anaesthesia, reducing perioperative airway events and ensuring smooth recovery. While dealing with ILD patient in sitting position, careful risk assessment is important because it will help us predict the course of the perioperative events. Balanced general anaesthesia using desflurane fulfilled the requirement of good depth and smooth recovery in this patient. Though there are reports of maintenance of anaesthesia with other inhalational agents, there are scanty reports of using desflurane in these cases.
\end{abstract}

Key words: Acoustic neuroma, desflurane, interstitial lung disease, sitting position craniotomy

\section{INTRODUCTION}

Association of vestibular tumours and interstitial lung fibrosis is rare; however, this association is seen with type I neurofibromatosis. The prevalence of this association is estimated to be $10-20 \%,{ }^{[1]}$ which is probably overstated.

Some of the anaesthetic challenges included maintaining a good depth of anaesthesia, reducing perioperative airway events and ensuring smooth recovery. With newer anaesthetic agents like desflurane, these goals can be attained with ease.

\section{CASE REPORT}

A 38-year-old woman weighing $45 \mathrm{~kg}$, who worked in a balloon factory, presented with headache, impaired

\begin{tabular}{|l|l|}
\hline \multicolumn{2}{|c|}{ Access this article online } \\
\hline Quick Response Code: & Website: \\
\hline & www.jnaccjournal.org \\
\cline { 2 - 2 } & \\
\hline
\end{tabular}

balance, non-productive cough and dyspnoea for the past 6 months. On auscultation, bilateral upper zone wheezes and basal crepitation were noticed. Computed tomography (CT) of the brain showed a soft tissue mass $(43 \times 3 \mathrm{~cm})$ of the left cerebellopontine angle, causing significant compression over the cerebellum. Her chest x-ray showed ground glass appearance in both the lung fields. Examination of sputum for acid-fast bacilli was negative. The lung condition was diagnosed astalcosis (type of interstitial lung disease). To confirm the diagnosis, high resolution CT scan of chest (HRCT) (generalized fibrosis and bronchiolitis obliterans of small airways), PFT (restrictive lung disease with no improvement post bronchodilators) and room air ABG: pH-7.412, $\mathrm{PCO}_{2}-47.4, \mathrm{PO}_{2}-87.6, \mathrm{SO}_{2}-96.7 \%, \mathrm{HCO}_{3}-28.3 \mathrm{mEq}$.was done. The patient was away from work for almost a year because of her neurological condition, and as a result her lung condition (talcosis) improved slightly. She was treated preoperatively with low dose steroid and $\mathrm{N}$-acetylcysteine nebulisation. The neurological symptoms progressed rapidly, and she was thus posted for craniotomy.

Pre-anaesthetic work up included haemoglobin $11.3 \mathrm{~g} / \mathrm{dl}$, white blood cell count 10,300/cumm and platelet count

Department of Anaesthesiology, B. Y. N. L. Charitable Hospital, Mumbai-Central, Mumbai, Maharashtra, India

Address for correspondence:

Dr. Deepa Suvarna, 1104 Raj Heritage Tower, Laxman Mhatre Road, Borivali (West), Mumbai - 400 103, Maharashtra, India.

E-mail: doctordeepas@yahoo.co.in 
of 2,36,000/cumm. Kidney and liver functions were normal, with random blood glucose of $145 \mathrm{mg} \%$. Electrocardiogram (ECG) was normal, and 2D echo showed LVEF-60\% andtype1 diastolic dysfunction with mild pulmonary hypertension.

After obtaining informed valid consent, the patient was transferred to the operation theatre. Intraoperative monitoring included oxygen saturation, blood pressure (invasive blood pressure), ECG, end-tidal $\mathrm{CO}_{2}$, body temperature, central venous pressure (CVP) and urine output. Baseline heart rate (HR) was $90 /$ minute and blood pressure (BP) was 130/80 $\mathrm{mmHg}$ in right arm supine position with bilateral normal air entry and normal heart sounds. An $18 \mathrm{G}$ peripheral intravenous (iv) line was inserted in the left arm and $500 \mathrm{ml}$ of normal saline was given as a preload. She was pre-medicated with iv glycopyrrolate $0.2 \mathrm{mg}$, iv ondansetron $4 \mathrm{mg}$, iv dexamethasone $8 \mathrm{mg}$ and iv fentanyl $100 \mu \mathrm{g}$. General anaesthesia was induced with iv propofol $100 \mathrm{mg}$, vecuronium $6 \mathrm{mg}$ and trachea intubated. Anaesthesia was maintained using desflurane 0.4-0.6 MAC (2-4\%) with low flows and intermittent boluses of iv fentanyl and vecuronium. Intraoperatively, the patient was ventilated using volume-controlled mode with low tidal volume $(6 \mathrm{ml} / \mathrm{kg})$, rate $12-14 / \mathrm{min}$ and PEEP of $4 \mathrm{~cm}$ of $\mathrm{H}_{2} \mathrm{O}$. Peak airway pressures were $22-23 \mathrm{~cm}$ of $\mathrm{H}_{2} \mathrm{O}$ in sitting position. Central venous and radial arterial cannulation was done. The CVP was $8-10 \mathrm{~cm}$ of $\mathrm{H}_{2} \mathrm{O}$, and arterial $\mathrm{BP}$ was 128/68 mm Hg. The patient was given sitting position (as per surgical needs) with constant monitoring. Intraoperatively mean arterial pressure was maintained in the range of $65-75 \mathrm{~mm} \mathrm{Hg}$, pulse rate $70-90 / \mathrm{min}$, CVP8- $10 \mathrm{~cm} \mathrm{H}_{2} \mathrm{O}$, end-tidal $\mathrm{CO}_{2}$ of $35 \pm 2 \mathrm{mmHg}$ and urine output of $1 \mathrm{ml} / \mathrm{kg} / \mathrm{hr}$. Pulse oximeter showed saturation 98-100\%. Intraoperative arterial blood gas (ABG) was done at various intervals in sitting position [Table 1].

The surgery lasted for 5 hours with blood loss of $450 \mathrm{ml}$. At the end of the surgery, neuromuscular blockade was reversed. Patient was extubated within 5 minutes of discontinuing desflurane after checking for protective reflexes. Aldrete score of $>9$ was obtained within 10 minutes. The patient was then shifted to post anaesthesia care unit for monitoring and nebulization. She was shifted to the ward the following day and discharged home on day 7 of surgery.

Table 1: Intraoperative arterial blood gas values

\begin{tabular}{lcccc}
\hline Intraoperatively & $\mathbf{p H}$ & $\mathbf{P C O}_{2}$ & $\mathbf{S O}_{\mathbf{2}}(\mathbf{\%})$ & $\mathbf{H C O}_{3}^{-}$ \\
\hline $1^{\text {st }} \mathrm{hr}$ & 7.352 & 47.4 & 98.7 & $25.3 \mathrm{mEq}$ \\
$2^{\text {nd }} \mathrm{hr}$ & 7.381 & 45 & 98.7 & $25 \mathrm{mEq}$ \\
$4^{\text {th }} \mathrm{hr}$ & 7.345 & 42 & 98.4 & $24.8 \mathrm{mEq}$ \\
$5^{\text {th }} \mathrm{hr}$ & 7.395 & 41.7 & 99.7 & $25 \mathrm{mEq}$ \\
\hline
\end{tabular}

\section{DISCUSSION}

Our case was distinguished by the presence of acoustic neuroma and having occupational talcosis (type of interstitial lung disease) as comorbidity. Association of vestibular tumours and interstitial lung fibrosis is rare. However, it is seen with type I neurofibromatosis with incidence of $10-20 \%{ }^{[1]}$ A good quality CT scan of the chest (HRCT), pulmonary function test (PFT) and total lung carbon monoxide tests give an idea of the extent of fibrosis and disability. A 6-minute walk test is also a good way of assessing the patient's functional status and is of prognostic value. ${ }^{[2]}$ Currently, treatment involves a low dose of steroids, azathioprine and $\mathrm{N}$-acetylcysteine. ${ }^{[2]}$

\section{Anaesthesia considerations}

Our patient was away from work for almost a year because of acoustic neuroma, and so her lung showed moderate restrictive changes only. In talcosis, lung condition may remain the same for long periods or it may change quickly depending on how long the patient is away from her occupation. ${ }^{[3]}$ This class of patients has a decreased functional residual capacity (FRC) and hence they tend to desaturate quickly, particularly before intubation (period of apnoea) and after extubation. Thus, there is aneed to minimise ventilation depression, which may persist into the postoperative period. ${ }^{[4]}$ The goals of mechanical ventilation are to maintain adequate ventilation and oxygenation while minimizing the risk of barotrauma, volutrauma and ALI. Potential strategies to minimize airway pressures include using high I:E ratio (1:1 to 1:2) as well as low-tidal volume in conjunction with high respiratory rate. A decrease in FRC leads to rapid induction with inhalational anaesthetics by faster achievement of alveolar concentration. Desflurane was used as it is least soluble and is not affected by changes in ventilation. In pulmonary fibrosis, the lung compliance is decreased to a small extent, but this is offset by a reduction in airway resistance. ${ }^{[5,6]}$

Hypotension and hemodynamic instability are commonly associated with the sitting position during anaesthesia, resulting primarily from a sudden decrease in intrathoracic blood volume. ${ }^{[7]}$ To counteract this physiological response, anaesthesiologists frequently reduce the concentration of inhaled anaesthetic, exposing patients to potential risk of being inadequately anaesthetised ${ }^{[7]}$ In our patient, reducing the depth of anaesthesia would result in further V/Q mismatch because of increased airway pressures. Anaestheticagents generally suppress baroreceptor function in clinically relevant concentrations; however, desflurane exhibits a unique autonomic physiology that preserves reflex sympathetic response to acute hypotension in anaesthetized humans beings. ${ }^{[7]}$ It is thus possible that 
challenging the baroreceptor reflex via altering body position during desflurane anaesthesia mediates a central effect on anaesthetic response (i.e. increasing anaesthetic demand). However, a study done by Lin et al. concluded that sitting position does not alter desflurane anaesthetic requirement for immobility. ${ }^{[7]}$ For desflurane, cardiac output does not affect the uptake. When anaesthetised patients were raised to the sitting position, desflurane preserved cerebral oxygenation better than propofol at equipotent concentrations in terms of BIS. ${ }^{[8]}$ Therefore, desflurane should be considered during surgeries in the sitting position, especially in patients with increased risk of cerebral ischaemia.

We stress the need for attentive monitoring to deal with venous air embolism, as this potentially grave complication would be detrimental. Desflurane requires less downward titration in long surgical procedures to achieve a rapid emergence by virtue of decreased tissue saturation. Restrictive lung disease contributes to postoperative pulmonary complications, as co-existing decreased lung volumes make it difficult to generate an effective cough to remove secretions from the airway. ${ }^{[4]}$ In our patient, depth of anaesthesia had to be maintained until the end to prevent airway events and achieve complete recovery; using desfluraneas maintenance was most useful.

We would like to conclude that using newer inhalational agents in such cases is prudent, as they offer precise control over the depth of anaesthesia and enable early recovery, thus facilitating immediate postoperative neurological assessment and avoiding adverse airway events. However, more cases need to be studied to define the role of desflurane.

\section{REFERENCES}

1. Davis SA, Kaplan RL. Neurofibromatosis and interstitial lung disease. Arch Dermatol 1978;114:1368-9.

2. Sen T, Udwadia Z, Retrospective F. Study of Interstitial Lung Disease in a Tertiary Care Centre in India. Indian J Chest Dis Allied Sci 2010;52:207-112.

3. Bourke SJ. Interstitial lung disease: Progress and problems. Postgrad Med J 2006;82:494-9.

4. Restrictive lung disease. Anaesthesia and Co-existing disease. In: Robert K, Stoelting, Stephen F, Dierdorf, editors. $4^{\text {th }}$ ed.; 2002. p. 215-6.

5. Carron M, Marchet A, Ori C. Supreme laryngeal mask airway for laproscopic cholecystectomy in patient with severe pulmonary fibrosis. Br J Anaesth 2009;103:778-9.

6. Linton RA. Pulmonary Ventilation. A Practice of Anesthesia. $5^{\text {th }}$ ed. Wylie and Churchill Davidson London; 1985. p. 72.

7. Lin CM, Wu CT, Lee ST, Lui TN, Huang CC, Li AH, et al. Sitting position does not alter minimum alveolar concentration for desflurane. Can J Anesth 2007;54:523-30.

8. Kwak HJ, Lee KC, Kim HS, Lee DC. The changes of regional cerebral oxygenation in the beach chair position for shoulder arthroscopy: Desflurane vs propofol. Eur J Anaesthesiol 2012;29:103.

How to cite this article: Suvarna D, Baliarsing L, Gujjar P, Agarwal R. Management of a patient undergoing sitting position craniotomy for acoustic neuroma with co-existing interstitial lung disease. $\mathrm{J}$ Neuroanaesthesiol Crit Care 2015;2:58-60.

Source of Support: Nil, Conflict of Interest: None declared. 